\title{
Does Peace Trickle Down? Micro-Level Evidence from Africa*
}

\author{
Martin Ottmann $^{\dagger} \quad$ Felix Haass
}

August 25, 2017

\begin{abstract}
Do peace agreements generate socio-economic peace dividends for citizens in post-war countries? While much research has focused on the elite level implications of peace agreements for the survival of peace, little is known about the micro-level, redistributive effects of peace agreements. We investigate the impact of peace agreement provisions and their implementation-specifically power-sharing arrangements—on individually reported measures of well-being. Building on a political economy theory of post-war politics, we conceptualize rebel organizations as political organizations that engage in distributive politics after conflict. As a result of such politically motivated redistribution, we expect an uneven manifestation of peace dividends on the micro-level that accumulates over the long-term. Specifically, we hypothesize that individuals with ethnic ties to rebel organizations that secure political power through a peace agreement perceive their well-being better than individuals without these links. To test this argument, we link data from recent Afrobarometer surveys to information on individuals' ethnic ties to rebel organizations in power-sharing arrangements in four African post-war countries. Controlling for a battery of factors that might simultaneously predict an ethnic group's propensity to gain political power and their members' well-being, results from a wide range of fixed effects specifications indicate support for our hypothesis. Peace trickles down, but not to everyone equally.
\end{abstract}

*We acknowledge support from the German Research Foundation (OT 494/1-1, ME 1701/7-1). Authors are listed in reverse alphabetical order. Equal authorship is implied. Paper prepared for the $113^{\text {th }}$ Annual Meeting of the American Political Science Association, 31 August-3 September 2017, San Francisco, California, USA. Early draft—comments and feedback welcome; please do not cite without permission.

'International Development Department, School of Government and Society, University of Birmingham, Birmingham B15 2TT, United Kingdom (e-mail: m.ottmann@bham.ac.uk; website: https://martinottmann.com/).

Arnold-Bergstraesser-Institute, Windausstr. 16, 79110 Freiburg and GIGA German Institute of Global and Area Studies, Neuer Jungfernstieg 21, 20354 Hamburg, Germany (e-mail: felix.haass@gigahamburg.de; website: https://felixhaass.github.io/). 


\section{Introduction}

Peace agreements have become one of the most common instruments for battlefield opponents to end internal armed conflicts (Kreutz 2010). Such agreements dramatically reshape a post-war country's political landscape. Through peace agreements, government and rebel representatives renegotiate type and extent of access to political power. This is no small feat in societies where the very question of access to political power has sparked violent insurgency. So far, scholarly research has mostly focused on the question why some of these agreements survive while others are unable to prevent a relapse into conflict (e.g., Jarstad and Sundberg 2007; Hartzell and Hoddie 2007; Joshi, Melander, and Quinn 2017; Ottmann and Vüllers 2015). Equally important, however, is the question whether peace agreements-and the redistribution of political and economic power they entail for elites at the macro-level-affect economic well-being of individual citizens in post-war societies?

The alleviation of poverty and economic marginalization of individual citizens is essential for successful post-war economic recovery. Such recovery can narrow economic horizontal inequalities and mitigate individual motivations for renewed rebel recruitment (Blattman and Miguel 2010; Humphreys and Weinstein 2008; Weinstein 2007). Once former belligerents feel physically safe and their economic needs are satisfied, they can credibly commit to upholding negotiated settlements and a legitimate peace can emerge (Wallensteen 2015). Consequently, successful economic recovery is a crucial step towards breaking the "conflict trap" (Collier et al. 2003). Past research already offers important insights on the macro-level determinants and dynamics of post-war economic recovery (e.g., Addison and Murshed 2003; Flores and Nooruddin 2009; Garriga and Phillips 2014). What is still missing though is a better understanding of the micro-level, redistributive effects of peace agreements underpinning post-war economic recovery. A number of questions are in need of an answer: Do only elites benefit from bargains at the negotiation table? Or is there a broader peace dividend-and how is it distributed and perceived among the population? Do peace agreements create more "losers" than "winners" on the ground and therefore sow the seeds for future civil war recurrences?

In this study, we address these questions. We shift the focus to the impact of peace agreement provisions and their implementation-particularly power-sharing arrangements—on individually reported measures of well-being. Building on a political economy theory of post-war politics, we conceptualize rebel organizations as political entities that engage in distributive politics to generate support among the population after conflict (Kramon and Posner 2016; Burgess et al. 2015). As a result of such politically motivated redistribution, we expect an uneven manifestation of peace dividends on the micro-level that accumulates over the long-term. Rebels that were supported by one 
or several ethnic groups are more likely to cater to their ethnic constituencies once a conflict ends-and power-sharing arrangements propel rebel elites into a position to do so. Consequently, we hypothesize that individuals with ethnic ties to rebel organizations that secure political power through a peace agreement report higher levels of well-being than individuals without these links.

To test this theory empirically, we exploit the strong ethnic dimension of civil conflicts in Africa (Roessler 2016). In this context, group-level variation of rebel organizations' access to power in the wake of a peace agreement allows us to link elite-level bargains to their co-ethnics' reported levels of well-being. Specifically, we combine data from recent Afrobarometer surveys with information on individuals' ethnic ties to rebel organizations in power-sharing arrangements in four West African post-war countries. We match data on ethnic ties between rebel organizations from the Ethnic Power Relations (EPR) dataset to fine-grained information on rebels' participation in power-sharing arrangements from the Power-Sharing Event Dataset (PSED). This enable us to trace the impact of different dimensions of power-sharing across different types of ethnic links to rebel organizations.

Across a wide range of models, we uncover a statistically and substantively significant positive effect of respondents' ethnic representation in power-sharing arrangements at the elite level on their reported level of well-being. Depending on the respective model specification, respondents with an ethnic power-sharing link answer Afrobarometers' question "In general, how would you describe your own present living conditions?" between 0.2 and 0.8 points higher than individuals without a power-sharing link. We identify the effect of power-sharing representation by controlling for a number of variables that predict a rebel organizations' participation in a power-sharing arrangement, such as civil war intensity, and fixed effects that capture an ethnic groups' power status prior to the peace agreement. Moreover, we rely purely on within-country variation, accounting for unobservable and observable factors that could drive both power-sharing and individual level well-being on the country level. The results are robust to a series of additional tests that account for alternative explanations, such as a country's general tendency for ethnic favoritism, possible effects of ethnic power transitions between the peace agreement and survey rounds, as well as interviewer effects. Peace trickles down, but not to everyone equally.

This paper makes a number of notable contributions. First, we add to the debate about the potential of political institutions to address inequality and grievances in post-war societies. Existing studies on this topic have largely focused on the macrolevel effects of institutions. They predominantly study whether post-war institutions, such as power-sharing, can mitigate the security dilemma among competing groups and thus create durable peace (e.g., Cederman, Gleditsch, and Buhaug 2013). The mechanisms proposed in these studies generally remain on the elite or group level, 
ranging from group-level accommodation on the political level, to the "buying out" of rebel elites (Haass and Ottmann 2017; Tull and Mehler 2005). Yet this elite-focus has generated a blind spot regarding the micro-level effects of post-war institutions. This has led Cederman and Vogt (2017) to reemphasize Blattman and Miguel's observation that "[t]he social and institutional legacies of conflict are arguably the most important but least understood of all war impacts" (Blattman and Miguel 2010, 42). Our paper addresses this gap.

Second, our results help to clarify the debate about the conditions under which ethnic favoritism and redistribution become a salient category of politics in Africa (Francois, Rainer, and Trebbi 2015; Posner 2005; Robinson 2014). The broader study of ethnic politics in Africa has made considerable use of micro-level data to uncover ethnicity as a key factor that shapes politics (Habyarimana et al. 2007; Kramon and Posner 2016; Franck and Rainer 2012). Our study, however, is among the first to identify, theorize, and provide quantitative evidence how the particular context of an ethnically charged post-war environment shapes ethnic politics on the micro-level.

\section{Ethnicity, Horizontal Inequalities, and Civil War}

To understand how peace agreements-and, more specifically, ethnic representation through rebel groups in a power-sharing arrangement-shape individual levels of wellbeing after conflict, we draw on concepts from the literature on horizontal inequalities: ethnicity and politically relevant ethnic groups, group grievances that arise from these inequalities, and rebel organizations that mobilize ethnic grievances through an armed insurgency (Cederman, Gleditsch, and Buhaug 2013; Cederman and Vogt 2017).

Peace agreements are attempts to restructure political power relations among battlefield opponents in the aftermath of civil conflict (Hartzell and Hoddie 2007; Licklider 1995; Wagner 2000; Wittman 1979). Following a prominent strand in the literature, we conceptualize civil conflicts as the violent escalation of horizontal political and social inequalities along ethnic fault lines. ${ }^{1}$ While other social cleavages than ethnicity can lead to the escalation of civil conflicts (such as the recently pacified ideology-based conflict between the FARC and the government of Colombia), our focus on conflicts with an ethnic dimension helps us to clearly define the theoretically relevant actors and mechanisms at play.

The analytical starting point in this framework is a politically relevant ethnic group. "Ethnicity" in this context refers to "any subjectively experienced sense of commonality

\footnotetext{
${ }^{1}$ Horizontal and political inequalities are "inequalities in economic, social or political dimensions or cultural status between culturally defined groups" (Stewart 2008, 3).
} 
based on the belief in common ancestry and shared culture" whereas "politically relevant" denotes a situtation in which "at least one political organization claims to represent [an ethnic group] in national politics or if its members are subjected to state-led political discrimination" (Cederman, Wimmer, and Min 2010, 98f). The political saliency of an ethnic group identity, combined with the group's political exclusion from political power can spark a grievance-based armed rebellion (Cederman, Gleditsch, and Buhaug 2013; Cederman, Weidmann, and Gleditsch 2011).

Two factors that link ethnonationalist grievances to the onset and continuation of armed insurgencies are relevant for our discussion about the socio-economic effects of peace agreements. The first is a rebel organization's ability to mobilize political action on the grounds of these group-based grievances (Cederman, Gleditsch, and Buhaug 2013; Weinstein 2007). Ethnic identity provides the social networks, the emotional attachement, as well as the socio-psychological in-group/out-group frames necessary for political elites to overcome free-rider problems inherent in collective action dilemmas (Cederman, Gleditsch, and Buhaug 2013; Olson 1971). Second, elites also need to actively organize an insurgency. In a sense, mobilization and overcoming the collective action problem is the first step in an armed insurgency, while successfully overcoming the logistical hurdles of organizing a rebellion is necessary to translate this collective action into a sustained armed insurgency (Ottmann 2017; Weinstein 2007). These logistical hurdles include recruitment of soldiers, maintaining support from the local population, intelligence gathering, territorial control, and many more (Kalyvas 2006). In conflicts with a distinct ethno-political dimension, many of these logistical hurdles are linked to the ethnic group: recruitment along ethnic lines, support from co-ethnic civilians, and territorial control—including public goods provision in this territory-in an geographically separated ethnic homeland (Wucherpfennig et al. 2012).

Once peace agreements with power-sharing arrangements accommodate rebel organizations into various positions of power, both dimensions of conflict onset-mobilization and organization along horizontal inequalities-directly play into the mechanisms through which peace agreements at the elite level shape individual well-being in the aftermath of conflict. We start from the assumption that peace agreements bring into power elites from rebel organizations that have fought on behalf of an ethnic group (or at least have claimed to fight on behalf of such a group). In this sense, a peace agreement represents a fundamental political change in two dimensions: First, it symbolizes the transition from war-time politics to peaceful competition in the political arena. Second, peace agreements also represent a change in an ethnic group's access to power. Both war-to-peace transitions and change in power access imply that rebel elites now need to solidify and expand their political power differently than during war. 


\section{Ethnic Favoritism after Civil War}

We integrate this understanding of ethnicity and civil wars into a framework that builds on ethnic politics in Africa, particularly ethnic favoritism and clientelism (Franck and Rainer 2012; Posner 2005). This enables us to trace the institutional and social legacies of conflict (Blattman and Miguel 2010) and, specifically, to generate predictions about the precise conditions under which power-sharing at the elite-level trickles down to the individual level. We identify three general channels how rebel elites can generate political support—channels that ultimately also shape individual levels of well-being.

The first channel concerns distributive politics and ethnic favoritism. Common ethnic origin as a channel through which elites can selectively target public goods has long been recognized as a key strategy of political elites to generate political support (Burgess et al. 2015; Eifert, Miguel, and Posner 2010; Golden and Min 2013; Jablonski 2014). This channel builds on the notion of rent- and office-seeking political elites in weakly institutionalized politics (Bratton and Van de Walle 1994; Bueno de Mesquita et al. 2003). In an environment where the lack of strong institutions makes general policy commitments less credible, citizens prefer clientelist policies (Lieberman 2015)—and ethnicity provides a credible frame along which elites will structure such clientelist politics and "buy" political support (Stokes et al. 2013).

Mobilization and organization along horizontal ethnic inequalities during conflict facilitates the selective distribution of goods among rebel elites and their co-ethnic supporters. If rebel groups have mobilized along ethnic lines, they are also likely to use ethnic frames to generate political support after conflict, either at the ballot box, or, in less democratic regimes, through the particularistic provision of goods along the very identity lines that have proved successful during war: their co-ethnics. Similarly, rebel elites that have organized their insurgent groups around ethnically defined categories, e.g. recruitment, can rely on war-time networks of mid-level commanders as brokers. These brokers act as immediaries between elites and individual citizens and have a crucial role in handing out selective goods (Stokes et al. 2013; Themnér and Utas 2016; Utas 2012).

The second channel through which co-ethnicity between individual citizens and elites in power can improve individual well-being is co-ethnicity as cognitive heuristic about policy making. Building on a large literature in sociology, political science, and social psychology, Lieberman and McClendon $(2013,576)$ for instance, argue that "ethnicity can serve as a cognitive heuristic for interpreting problems and policies." In an environment in which programmatic promises and platforms are rare and even more rarely credible, co-ethnicity between citizens and politicians ensures citizens that politicians will act in their group's political interests (Franck and Rainer 2012). This 
argument rests in part on a mechanism of shared preferences among co-ethnics. This mechanism posits that ethnicity is a source of information about the preferences-coethnic leaders better know what their ethnic group "wants."

Again, mobilization and organization of armed insurgencies along ethnic lines during a civil conflict amplifies the information function of co-ethnics that come to power through peace agreements. Having staged a rebellion on the grounds of ethnic claims increases the credibility of rebel elites that they know the preferences of their co-ethnics. They have, after all, risked their lives "for the cause" - the ultimate signal that they have their co-ethnics' interests at heart. Similarly, organizing rebellion through ethnic networks and control of "ethnic homelands" sends strong signals of preference alignment. Different preferences along ethnic lines are famously visible in differing preferences about the geographical location of public investments-ethnic elites typically prefer to allocate resources to their ethnic homelands (Bates 1974; Kasara 2007). Thus, rebels that have fought for and held their ethnic groups' territory during civil war, are more credible to have their co-ethnics' political interests at heart.

The final channel focuses on physical security. Co-ethnics in power also improve well-being through the provision of physical security for group members. Many ethnonationalist insurgencies are driven by a sense of fear, often triggered by state repression of particular ethnic minorities (Cederman, Gleditsch, and Buhaug 2013). Having a rebel organization in power that has fought on behalf on a citizens' ethnic group signals to this ethnic groups' members that they are now better protected than before. Co-ethnics now exert political control within the state that might have repressed memebers of an ethnic group, creating the opportunity to veto violent actions directed against that group (Gates et al. 2016; Padró i Miquel 2007).

In this channel, too, mobilization and organization of ethnic rebellion amplify a rebel organization's ability to improve individual citizens' well-being. If rebels mobilize on a platform of ethnic fears, being in power after a peace agreement gives them the credibility to signal that they are now in a position to alleviate these fears. Moreover, peace agreements often include provision for military integration, both at the command and the rank-and-file level. Similarly to the security signals of political participation, such military integration signals to ethnic constituents that their ethnic group will have a say in future military matters, easing fear for repression through the military.

Taken together, the material, psychological, and physical utility generated by coethnic rebel representatives and citizens implies that the benefits for individual well-being will be distributed unequally in a post-war society. Instead, we expect that individuals with ethnic links to rebel organizations included in power-sharing arrangements will report higher levels of well-being than individuals without these links. 


\section{Data}

We test our hypothesis using individual-level data from Round 5 and 6 of the Afrobarometer survey. In particular, we focus on a sample of 4,758 respondents drawn from four West African post-war countries: Ivory Coast, Liberia, Senegal, and Sierra Leone. Each survey has been conducted between 9 and 12 years after the peace agreement.

\subsection{Sample Selection}

Our case selection is guided by two considerations. First, we need to clearly link citizens in post-war states to the relevant government and rebel actors involved in the peace agreement in order to test the hypothesized effect of power-sharing on citizens' wellbeing. To establish such a link, we focus on African civil wars which are characterized by the prevalence of ethnic support networks (Clapham 1998; Denny and Walter 2014). Ethnic groups in Africa feature dense social networks resulting in high levels of intragroup trust and low-cost access to information about co-ethnics' preferences and behavior. These factors facilitate recruitment into armed groups and also ensure the flow of political and military resources from individuals on the ground to the military organizations of government and rebels (Kalyvas 2006; Weinstein 2007). We therefore aim to identify citizens' ethnic identity and link it to the government and rebel signatories of the peace agreements under analysis.

Second, our focus on Africa allows us to circumvent the dearth of micro-level data frequently hampering research on post-war countries. The Afrobarometer surveys provide high-quality comparative data on citizen attitudes towards democracy and governance, markets, and civil society for many African countries. There are not many alternative data source offering comparably comprehensive and extensive individuallevel data on post-war countries. Moreover-and of particular interest for our research objective-recent Afrobarometer survey includes detailed questions on respondents' ethnic identities, their salience, and whether they perceive themselves as being treated fairly.

However, it also follows from these two considerations that the sample under analysis cannot be representative of the larger universe of post-war countries. This is even more so as we have to further restrict our sample due to data limitations in the available Afrobarometer survey rounds. As Afrobarometer explicitly focuses on minimally democratic countries with no ongoing large-scale violence, for instance, survey rounds have only been conducted in 10 of the 19 African countries in which a civil war was followed by a peace agreement between 1989 and 2006 (Gleditsch et al. 2002; Harbom, Högbladh, and Wallensteen 2006). Due to our interest in citizens' well-being-roughly-ten years 
after the peace agreement, we have to further restrict our sample to six countries. Finally, two more countries have to be excluded as the respective Afrobarometer surveys did not ask respondents about their ethnic identities.

\subsection{Dependent Variables}

We are interested in whether respondents perceive an improvement in their well-being once a civil war has been terminated through a peace agreement between the government and rebels. The term "well-being" captures citizens' subjective opinion of their general living conditions. This predominantly socio-economic definition of the term builds on its usage in economics and has a number of advantages in our context (Kahneman and Krueger 2006).

First, while well-being mostly captures economic aspects of life, such as income, education, employment, or access to food, water, medical care, or electricity, it also captures a more general outlook on life. This is beneficial from a theoretical perspective, since the three postulated theoretical channels-material benefits, psychological satisfaction, and physical security-all capture slightly different aspects of well-being which we subsume under the conceptual category "well-being." Second, direct survey measures of income in low-income countries are often unreliable and difficult to compare across specific contexts (Howe et al. 2009). While our broader concept of well-being is arguably less precise than numerical measures of income in, for instance, US dollars, we believe it captures more reliably the respondents general living conditions than alternative concepts. Third, a broader concept of well-being circumvents problems of issue-specificity in distributive politics. Kramon and Posner (2013) show that observed patterns of ethnic favoritism can depend on the respective good studied by the researcher. The reason for this is that different goods gain politically depending on the specific political and social context - the additional utility of preferentially allocating food, for instance, is not very high when food is not scarce. By abstracting away from the specific indicators of well-being, such as access to food, water, electricity, or medical care, we address this problem while still being able to trace patterns of distributive politics.

We use three Afrobarometer survey items to explore respondents' post-war wellbeing. Table 1 provides an overview of these variables and their respective value labels. It also reports the overall number of observations, mean and standard deviation. As our main dependent variable, we use question Q4b (Q3b in Round 5): "In general, how would you describe: Your own present living conditions?". This question captures the aforementioned general outlook on life of the respondents. On average, citizens in our four West African post-war countries report a fairly neutral view of their living conditions. This also the case if we look at the mean of this variable for each country. It varies 
Table 1. Overview of Dependent Variables

\begin{tabular}{|c|c|c|c|c|}
\hline Question & Value Labels & $\mathrm{N}$ & Mean & $\mathrm{SD}$ \\
\hline $\begin{array}{l}\text { In general, how would you describe: Your } \\
\text { own present living conditions? }\end{array}$ & $\begin{array}{l}1=\text { very bad, } 2=\text { fairly } \\
\text { bad, } 3=\text { neither good } \\
\text { nor bad, } 4=\text { fairly } \\
\text { good, } 5=\text { very good }\end{array}$ & 4,733 & 2.96 & 1.26 \\
\hline $\begin{array}{l}\text { In general, how do you rate your living } \\
\text { conditions compared to those of other } \\
\text { citizens [in the respective country]? }\end{array}$ & $\begin{array}{l}1=\text { much worse, } \\
2=\text { worse, } 3=\text { same, } \\
4=\text { better, } 5=\text { much } \\
\text { better }\end{array}$ & 4,622 & 3.17 & 1.01 \\
\hline $\begin{array}{l}\text { How often, if ever, are [members of the } \\
\text { respondent's ethnic group] treated unfairly } \\
\text { by the government? }\end{array}$ & $\begin{array}{l}0=\text { never, } \\
1=\text { sometimes, } \\
2=\text { often, } 3=\text { always }\end{array}$ & 4,571 & 0.47 & 0.85 \\
\hline
\end{tabular}

between 2.85 (Ivory Coast) and 3.06 (Liberia). Examining the overall frequencies for each response to the survey item, however, we observe that almost $40 \%$ of respondents report very bad or fairly bad living conditions and $43 \%$ record fairly good or very good living conditions. This division in assessments of living conditions is indicative of the overall high inequality in Africa (Lakner and Jirasavetakul 2016).

To further probe respondents' perceptions of their living conditions, we rely on two additional Afrobarometer survey items. First, we use question Q5 (Q4 in Round 5) asking "In general, how do you rate your living conditions compared to those of other citizens [in the respective country]?". This question serves as a robustness check of the previous assessment of respondents' living conditions. It explicitly explores how respondents' assess their living conditions relative to those of their fellow citizens. Summary statistics indicate that respondents have a slightly more positive perception of their living conditions when asked to compare themselves to their peers. Only $26 \%$ of respondents perceive their relative living conditions as much worse or worse. In contrast, almost $40 \%$ rate themselves as enjoying better or much better living conditions than their fellow citizens.

Finally, we use Q88a (Q84a in Round 5) to explicitly explore whether citizens' see their ethnic group as a whole as benefitting from being represented in a power-sharing arrangement. The question asks: "How often, if ever, are [members of the respondent's ethnic group ] treated unfairly by the government?". In line with our hypothesis, we expect power-sharing to have a negative effect on this variable. That is, respondents represented in national-level power-sharing are less likely to report that their ethnic group is treated unfairly. With this variable, we are able to directly test our assumption that ethnic favoritism is in play in post-war countries. The summary statistics indicate that most citizens do not see their groups treated unfairly. But there are differences between the countries in our sample. In Liberia and Senegal, $81 \%$ and $91 \%$ of respondents 
respectively see their ethnic groups as never experiencing unfair treatment. In Ivory Coast and Sierra Leone, however, only $50 \%$ and $62 \%$ of respondents respectively report no unfair treatment. ${ }^{2}$

\subsection{Explanatory Variables}

To establish a link between the Afrobarometer individual-level data and information on government and rebel involvement in power-shaing, we utilize respondents' answers to the question "What is your ethnic community, cultural group or tribe?". ${ }^{3}$ The large majority of respondents in our sample have provided this information. There are 12 missing values. 8 respondents only see themselves as citizens of their country and/or do not think in ethnic terms and 1 answered the question on ethnic identity with "Don't know". All these observations are dropped from the sample.

Overall, our Afrobarometer sample comprising respondents in Ivory Coast, Liberia, Senegal, and Sierra Leone lists 46 distinct ethnic groups. We assign these ethnic groups to the list of "politically relevant" ethnic groups compiled by the Ethnic Power Relations (EPR) dataset family (Vogt et al. 2015). ${ }^{4}$ By and large, the names of ethnic groups used in these two data sources are identical-apart from some negligible differences in spelling. However, there is no perfect overlap between Afrobarometer and EPR as the latter only includes "politically relevant" ethnic groups. While we are able to match 20 of the 21 EPR groups to Afrobarometer, ${ }^{5}$ there is no match for 24 Afrobarometer ethnic groups. ${ }^{6}$ In line with EPR terminology, we define these ethnic groups as "politically irrelevant". ${ }^{7}$

With this link between Afrobarometer and EPR, we are able to map each respondent in our sample to the government and rebel signatories to a peace agreement as recorded by PSED (Ottmann and Vüllers 2015). In order to make this connection, we rely on

\footnotetext{
${ }^{2}$ This discrepancy might be due to the overall number of respondents belonging to an ethnic group with a rebel link in each country. As shown in Table 2, Ivory Coast and Sierra Leone are those two countries where the rebel groups represented large shares of the overall population in each country. Interestingly, if we compare the response frequencies in each country for those ethnic groups with a rebel link to those without one, we observe that respondents with a rebel link report less frequently that their ethnic group is treated unfairly compared to those without a rebel link.

${ }^{3}$ This is question Q87 in the Afrobarometer Round 6 survey and Q84 in the Round 5 survey.

${ }^{4}$ Please see Vogt et al. (2015) for a definition of "politically relevant group". The EPR Atlas (Girardin et al. 2015) provides details on which ethnic groups are politically relevant in the section "Group Selection" of each country report.

${ }^{5}$ In Ivory Coast, EPR distinguishes between the "Baule (Akan)" and "Other Akans". Afrobarometer, in constrast, only lists the "Akan".

${ }^{6}$ In two cases, two Afrobarometer ethnic groups are assigned to one EPR ethnic groups. In Ivory Coast, the "Gur (Voltaïque)" and "Mandé du Nord" are subsumed under the EPR label "Northerners (Mande and Voltaic/Gur)". In Sierra Leone, the "Limba" and "Temne" are subsumed under the EPR label "Northern Groups (Temne, Limba)"

${ }^{7}$ We also regard the 14 respondents who responded to Q87/Q84 with "Others" as "politically irrelevant" ethnic groups.
} 
ACD2EPR (Wucherpfennig et al. 2012) which maps ethnic groups in EPR to rebel groups listed in the UCDP Armed Conflict Dataset (Gleditsch et al. 2002). As PSED relies on the same list of UCDP rebel groups to identify rebel group signatories to peace agreements, we are then able to identify which ethnic groups are represented by PSED rebel group signatories. Table 2 displays the rebel groups for each country and which ethnic groups in the countries are affiliated to these rebel organizations. It also reports the overall number of respondents for rebel-affiliated and unaffiliated ethnic groups.

For each peace agreement, we create aggregate power-sharing measures capturing whether power-sharing in a particular dimension (political, military, and economic) occurred for at least a month in a five-year post-war period. ${ }^{8}$ Table 2 lists which type of power-sharing can be found in each country. From this information, we create our main explanatory variable-Power-sharing - which measures whether any type of power-sharing arrangement has occurred at least once during the post-war period. ${ }^{9}$

The Afrobarometer-EPR link also enables us to add additional information on the history of violence and wartime power status for each ethnic group in our sample. The variable Battle deaths $(\ln )$ is a count variable based on UCDP data of all cumulative battle deaths "experienced" by the ethnic group through a rebel group link since beginning of the conflict and prior to the peace agreement year (Allansson, Melander, and Themnér 2017; Harbom, Melander, and Wallensteen 2008). ${ }^{10}$ The variable Power status measures the political status of an ethnic group in the year prior to the peace agreement ranked on a scale between 0 (=irrelevant, state collapse), 1 (=discriminated, powerless, selfexcluded), and 2 (=junior/senior) (Vogt et al. 2015). ${ }^{11}$

\section{Empirical Strategy}

To test our hypothesis, we conduct a cross-sectional analysis comparing the effect of power-sharing on citizens' well-being roughly ten years after the peace agreement across the four West African countries in our sample. Our "treatment" is being member of an ethnic group that gains power on the national level through a negotiated and implemented power-sharing arrangement. To isolate the effect of our treatment variable from confounding factors that simultaneously determine treatment assignment, we estimate the following ordinary least squares (OLS) specification: ${ }^{12}$

\footnotetext{
${ }^{8}$ There was no instance of territorial power-sharing in the four countries included in our sample.

${ }^{9}$ For robustness checks, we also create two count variables measuring the duration in months and the maximum number of power-sharing dimensions active throughout each peace agreement's post war period.

${ }^{10}$ If an ethnic group has an EPR link to more than one rebel group the counts are summed.

${ }^{11}$ Dominant and monopoly power status do not appear in our sample.

${ }^{12}$ We also run an ordered logit regression of our main models. Our findings remain robust to this alternative model specification.
} 
Table 2. post-war Countries, Rebel Organizations, and Ethnic Constituencies

\begin{tabular}{|c|c|c|c|c|}
\hline Country & Rebel group & Ethnic group & Power-sharing & $\begin{array}{l}\text { Number of } \\
\text { respondents }(\% \\
\text { of respondents in } \\
\text { country) }\end{array}$ \\
\hline \multirow[t]{2}{*}{ Ivory Coast } & FRCI & $\begin{array}{l}\text { Mandé du Nord, } \\
\text { Gur (Voltaïque), } \\
\text { Mandé du Sud }\end{array}$ & Political, Military & $510(43 \%)$ \\
\hline & $\begin{array}{l}\text { Ethnic Groups } \\
\text { with no Rebel } \\
\text { Links }\end{array}$ & Akan, Krou & & $687(57 \%)$ \\
\hline \multirow[t]{3}{*}{ Liberia } & MODEL & Krahn & $\begin{array}{l}\text { Political, } \\
\text { Economic }\end{array}$ & $58(5 \%)$ \\
\hline & LURD & Mandingo & $\begin{array}{l}\text { Political, } \\
\text { Economic }\end{array}$ & $27(2 \%)$ \\
\hline & $\begin{array}{l}\text { Ethnic Groups } \\
\text { with no Rebel } \\
\text { Links }\end{array}$ & $\begin{array}{l}\text { English, Gio, } \\
\text { Kpelle, Kru, } \\
\text { Mano, Dei, } \\
\text { Lorma, Bassa, } \\
\text { Grebo, Kissi, Vai, } \\
\text { Gola, Belle, } \\
\text { Mende, Gbandi }\end{array}$ & & 1103 (93\%) \\
\hline \multirow[t]{2}{*}{ Senegal } & MFDC & Diola & & $48(4 \%)$ \\
\hline & $\begin{array}{l}\text { Ethnic Groups } \\
\text { with no Rebel } \\
\text { Links }\end{array}$ & $\begin{array}{l}\text { Wolof, Pu- } \\
\text { laar/Toucouleur, } \\
\text { Serer, } \\
\text { Mandinka/Bambara, } \\
\text { Soninke, Maures, } \\
\text { Manjack, Balante }\end{array}$ & & $1135(96 \%)$ \\
\hline \multirow[t]{2}{*}{ Sierra Leone } & RUF & Temne, Limba & Military & $404(34 \%)$ \\
\hline & $\begin{array}{l}\text { Ethnic Groups } \\
\text { with no Rebel } \\
\text { Links }\end{array}$ & $\begin{array}{l}\text { Creole, Kono, } \\
\text { Mende, Yalunka, } \\
\text { Madingo, } \\
\text { Sherbro, Loko, } \\
\text { Susu, Kuranko, } \\
\text { Fulla, Kissi, Kru, } \\
\text { Vai }\end{array}$ & & $786(66 \%)$ \\
\hline
\end{tabular}

Notes: Political power-sharing encompasses arrangements in the national government and parliamentary quotas. Military power-sharing comprises the integration of rebel leaders in the national army command and the integration of rank and file fighters into national units. Economic power-sharing captures the established of joint natural resource commissions and the allocation of executive-level posts in state companies to rebel elites. 


$$
\text { Well-Being }_{\text {iec }}=\beta \text { Power-sharing }{ }_{e}+\mathbf{X}_{i e c}+\boldsymbol{\eta}_{e}+\boldsymbol{\gamma}_{c}+\epsilon_{i e c}
$$

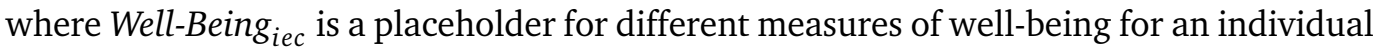
Afrobarometer respondent $i$, in country $c$ and ethnic group $e$. In most of our models,

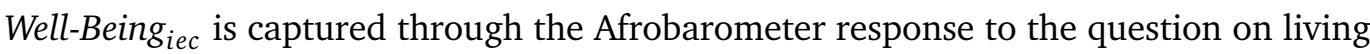
conditions (see above). Power-sharing ${ }_{e}$ is a dummy measure of the representation in power-sharing of an individual's ethnic group $e$ through a peace agreement. Our coefficient of interest is $\beta$, the estimated relationship between the representation of an individual's ethnic group in power-sharing and the individual's current level of reported well-being.

$\mathbf{X}_{i e c}$ denotes a vector of individual level covariates that largely capture predictors of individual well-being, such as the respondent's age (and age squared), gender, and whether the respondent lives in a rural location. The vector $\boldsymbol{\eta}_{e}$ consists of pre-treatment variables at the ethnic group level that might influence respondents' levels of well-being or their ethnic groups' probability to gain power through a peace agreement, such as the number of battle-related deaths and the pre-agreement power status of the ethnic group. The vector $\gamma_{c}$ denotes a set of country fixed effects that capture unobserved variables at the country-level that might make it both more likely for some ethnic groups to gain power in a country and that drive well-being (e.g., colonial history, or different country-specific averages of living conditions as reported above).

Some of our variables in Equation 1 do not vary at the individual level, but at the ethnicity level, most notably our main measure for Power-sharing $e_{e}$. Since this might introduce within-group clustering of the regression residuals we adjust standard errors for clustering at the ethnic group level. ${ }^{13}$

\section{Regression Results}

Estimates of Equation 1 are presented in Table 3. We begin with a bivariate regression of Power-sharing on living conditions in Model 1 and then add-in a stepwise mannercountry fixed effects (Model 2), respondent controls (Model 3), and ethnic group controls (Model 4). In Model 5, we use standard errors adjusted for two-way clustering within ethnic groups and within regions (Cameron, Gelbach, and Miller 2011). In Model 6, we use region fixed effects.

The coefficient of our explanatory variable-Power-sharing-is statistically significant with a positive sign in all models. This is consistent with our theoretical expectation that

\footnotetext{
${ }^{13}$ We use the list of Afrobarometer ethnic groups for the clustered standard errors.
} 
Table 3. Effect of Representation in Power-Sharing on Well-Being

\begin{tabular}{|c|c|c|c|c|c|c|}
\hline & Model 1 & Model 2 & Model 3 & Model 4 & Model 5 & Model 6 \\
\hline Power-sharing & $\begin{array}{r}0.52^{*} \\
(0.25)\end{array}$ & $\begin{array}{c}0.70^{* *} \\
(0.24)\end{array}$ & $\begin{array}{c}0.68^{* *} \\
(0.25)\end{array}$ & $\begin{array}{c}0.80^{* * *} \\
(0.10)\end{array}$ & $\begin{array}{c}0.80^{* * *} \\
(0.02)\end{array}$ & $\begin{array}{c}0.21^{* *} \\
(0.07)\end{array}$ \\
\hline \multicolumn{7}{|l|}{ Respondent controls } \\
\hline Age & & & $\begin{array}{c}-0.02^{* *} \\
(0.01)\end{array}$ & $\begin{array}{c}-0.02^{* *} \\
(0.01)\end{array}$ & $\begin{array}{r}-0.02^{*} \\
(0.01)\end{array}$ & $\begin{array}{c}-0.02^{* *} \\
(0.01)\end{array}$ \\
\hline Age (squared) & & & $\begin{array}{r}0.00^{*} \\
(0.00)\end{array}$ & $\begin{array}{r}0.00^{*} \\
(0.00)\end{array}$ & $\begin{array}{c}0.00^{*} \\
(0.00)\end{array}$ & $\begin{array}{r}0.00^{*} \\
(0.00)\end{array}$ \\
\hline Female & & & $\begin{array}{c}-0.08^{* *} \\
(0.03)\end{array}$ & $\begin{array}{c}-0.09^{* *} \\
(0.03)\end{array}$ & $\begin{array}{c}-0.09^{* *} \\
(0.03)\end{array}$ & $\begin{array}{r}-0.08^{*} \\
(0.03)\end{array}$ \\
\hline Rural location & & & $\begin{array}{c}-0.08 \\
(0.09)\end{array}$ & $\begin{array}{c}-0.09 \\
(0.08)\end{array}$ & $\begin{array}{c}-0.09 \\
(0.09)\end{array}$ & $\begin{array}{c}-0.16^{* *} \\
(0.05)\end{array}$ \\
\hline \multicolumn{7}{|l|}{ Ethnic group controls } \\
\hline Battle deaths (ln) & & & & $\begin{array}{c}-0.10^{* * *} \\
(0.02)\end{array}$ & $\begin{array}{c}-0.10^{* * *} \\
(0.02)\end{array}$ & $\begin{array}{c}-0.00 \\
(0.01)\end{array}$ \\
\hline Power status $=0$ & & & & $\begin{array}{l}0.00 \\
(.)\end{array}$ & $\begin{array}{c}0.00 \\
(0.00)\end{array}$ & $\begin{array}{l}0.00 \\
(.)\end{array}$ \\
\hline Power status $=1$ & & & & $\begin{array}{r}0.39^{+} \\
(0.22)\end{array}$ & $\begin{array}{r}0.39^{*} \\
(0.19)\end{array}$ & $\begin{array}{c}-0.17 \\
(0.32)\end{array}$ \\
\hline Power status $=2$ & & & & $\begin{array}{c}0.80^{* * *} \\
(0.13)\end{array}$ & $\begin{array}{c}0.80^{* * *} \\
(0.15)\end{array}$ & $\begin{array}{c}0.28^{* *} \\
(0.10)\end{array}$ \\
\hline Constant & $\begin{array}{l}2.86^{* * *} \\
(0.09)\end{array}$ & $\begin{array}{l}2.95^{* * *} \\
(0.08)\end{array}$ & $\begin{array}{l}3.55^{\text {*** }} \\
(0.17)\end{array}$ & $\begin{array}{l}2.85^{* * *} \\
(0.22)\end{array}$ & $\begin{array}{l}2.85^{* * * *} \\
(0.28)\end{array}$ & $\begin{array}{l}3.20^{* * *} \\
(0.28)\end{array}$ \\
\hline Number of respondents & 4733 & 4733 & 4703 & 4703 & 4703 & 4703 \\
\hline Number of ethnic groups & 44 & 44 & 44 & 44 & 44 & 44 \\
\hline Number of regions & 64 & 64 & 64 & 64 & 64 & 64 \\
\hline Country fixed effects & No & Yes & Yes & Yes & Yes & No \\
\hline Region fixed effects & No & No & No & No & No & Yes \\
\hline Adjusted $\mathrm{R}^{2}$ & 0.03 & 0.04 & 0.05 & 0.08 & 0.09 & 0.18 \\
\hline
\end{tabular}

The table reports OLS estimates. The unit of observation is an individual. Standard errors are clustered on ethnic groups in all models except for model 5 which uses multi-way standard errors clustered on ethnic groups and regions. $+,{ }^{*}, * *$, and ${ }^{* * *}$ indicate statistical significance at the $10,5,1$, and $0.1 \%$ levels.

respondents report higher levels of well-being when their ethnic group is represented in a national-level power-sharing arrangement. The effect size for Power-sharing ranges from 0.52 to 0.80 in Models 1 to 5 . Using Model 4 as our baseline specification, the coefficient size of 0.80 indicates that respondents with power-sharing representation report an assessment of their living conditions almost one category level higher than of those citizens which are not represented in national-level power-sharing. Only when we use region fixed effects, the effect size is considerably lower. However, this is to be expected as region-level variation accounts for substantial variation in living conditions across respondents-which is also apparent from the considerably higher $R^{2}$ in Model 6. Nevertheless, the effect size of 0.21 of Power-sharing is still positive and statistically significant. 
Table 4. Alternative Dependent Variables: Living Conditions Compared (Model 7) and Ethnic Group Treated Unfairly (Model 8)

\begin{tabular}{lcc}
\hline & Model 7 & Model 8 \\
\hline Power-sharing & $0.45^{* * *}$ & $-0.53^{* *}$ \\
& $(0.06)$ & $(0.18)$ \\
Constant & $2.79^{* * *}$ & $0.29^{+}$ \\
& $(0.18)$ & $(0.16)$ \\
\hline Number of respondents & 4595 & 4542 \\
Number of ethnic groups & 44 & 44 \\
Number of regions & 64 & 64 \\
Country fixed effects & Yes & Yes \\
Adjusted $\mathrm{R}^{2}$ & 0.11 & 0.16 \\
\hline
\end{tabular}

The table reports OLS estimates. The unit of observation is an individual. The respondent controls are Age and its squared term, Female, and Rural location. The ethnic group controls include pre-agreement battle related deaths and preagreement power status fixed effects. Standard errors are clustered on ethnic groups. ${ }^{+}, *, * *$, and ${ }^{* * *}$ indicate statistical significance at the $10,5,1$, and $0.1 \%$ levels.

By and large, the respondent controls and ethnic group controls behave as expected across all six models. Age and Female are statistically significant predictors for respondents' well-being. Rural location only becomes statistically significant once we include region fixed effects and we are able to pick up differences between urban and rural respondents within each region. ${ }^{14}$ Battle deaths $(l n)$ is statistically significant in Model 4 and 5 but not in Model 6. It appears that the inclusion of region fixed effects accounts for different levels of pre-agreement battle violence across regions. Finally, we find that respondents' belonging to an ethnic group which was already in power prior to the peace agreement is also associated with higher levels of well-being.

Table 4 reports the results of re-estimating Model 4 with two alternative dependent variables. Model 7 relies on the question asking respondents to comnpare their living conditions to those of their fellow citizens. In Model 8, we use the question whether members of the respondent's ethnic group have been treated unfairly as our dependent variable. In both models, Power-sharing behaves as expected and remains statistical significant. Representation in power-sharing improves the relative assessment of respondent's living conditions verifying the validity of our main dependent variable. Power-sharing also has a negative effect on respondents' perceptions regarding the question whether their ethnic group is treated unfairly. This lends support to our assumption

\footnotetext{
${ }^{14}$ In two separate models, we also estimated Model 4 with education and employment fixed effects to pick up differences in living conditions among employed/unemployed and educated/uneducated respondents. The results do not change substantially in these alternative model specifications. We do not report them here as education and employment are technically post-treatment variables which might potentially introduce bias (Angrist and Pischke 2009). For instance, a respondent's occupation might have changed due to patronage rewards after the peace agreement.
} 
that representation in power-sharing to respondents' well-being runs indeed through ethnic identity.

\subsection{Power-Sharing and General Patterns of Ethnic Favoritism}

An alternative explanation for the association between individuals' reported living conditions and their ethnic groups' representation in a power-sharing arrangement is that our findings simply reflect a general tendency for ethnic favoritism in a country. Our results could be driven by the fact that individuals' ethnic links to politicians improve their reported well-being in general-a proposition that is supported by a large literature on distributive politics and ethnic favoritism in Africa (Burgess et al. 2015; Kramon and Posner 2013). In this case, our results would not document the institutional effects of a peace agreement-i.e. an individual's ethnic group represented through a rebel organization in a power-sharing arrangement-but indicate a broader pattern of ethnic politics in post-war countries. Empirically, this proposition implies that our results should disappear once we control for an ethnic groups' general access to power, instead of capturing it only through the power-sharing variable.

Using Model 4 as starting point, we test this proposition in Table 5. In Model 9, we add the dummy variable Access to power one year after PA that captures whether a respondent's ethnic group had access to power after the peace agreement, regardless of whether this power access manifests itself through power-sharing with rebel organization or whether it reflects an ethnic groups' access to power through the government side of a peace agreement. ${ }^{15}$ Conditioning on country fixed effects and an ethnic group's power status prior to the peace agreement ${ }^{16}$ as well as our standard set of individual controls, Access to power one year after PA is positive, but only statistically significant at the $10 \%$ level. The coefficient of interest-Power-Sharing-is largely unaffected by controlling for an ethnic groups' general access to power and remains positive, large, and statistically significant.

In Model 10, we conduct an alternative test of the possibility that our documented effect of power-sharing simply reflects an improvement in an ethnic group's access to political power, regardless of whether or not the ethnic group was represented through a rebel organization in a power-sharing arrangement. The dummy variable Power upgrade after PA captures whether the power status of a respondent's ethnic group improved from before the peace agreement to after the peace agreement as coded by the EPR data

\footnotetext{
${ }^{15}$ This specification introduces a certain amount of collinearity between the Power-sharing variable and the Access to power one year after PA variable. However, variance inflation diagnostics do not indicate multicollinearity problems.

${ }^{16}$ Due to overlap between a group's ethnic power status before and after the peace agreement we cannot estimate Model 9 with our standard, more fine-grained set of ethnic power fixed effects, but collapse these to a dummy that reflects whether a group was in power prior to the PA or not.
} 
Table 5. Power-Sharing and Ethnic Power Access

\begin{tabular}{|c|c|c|c|c|}
\hline & Model 9 & Model 10 & Model 11 & Model 12 \\
\hline Power-sharing & $\begin{array}{l}0.80^{* * *} \\
(0.10)\end{array}$ & $\begin{array}{l}0.81^{* * *} \\
(0.09)\end{array}$ & $\begin{array}{l}1.08^{* * *} \\
(0.20)\end{array}$ & $\begin{array}{l}0.72^{* * *} \\
(0.15)\end{array}$ \\
\hline \multicolumn{5}{|l|}{ Ethnic group power changes } \\
\hline Access to power one year after PA & $\begin{array}{r}0.39^{+} \\
(0.22)\end{array}$ & & & \\
\hline Power upgrade after PA & & $\begin{array}{c}0.50^{*} \\
(0.21)\end{array}$ & & \\
\hline Power upgrade after PA and before survey round & & & $\begin{array}{r}-0.32^{+} \\
(0.16)\end{array}$ & \\
\hline Power downgrade after PA and before survey round & & & & $\begin{array}{c}-0.10 \\
(0.12)\end{array}$ \\
\hline Constant & $\begin{array}{l}2.85^{* * *} \\
(0.22)\end{array}$ & $\begin{array}{l}3.16^{* * *} \\
(0.21)\end{array}$ & $\begin{array}{l}2.67^{* * *} \\
(0.24)\end{array}$ & $\begin{array}{l}2.88^{* * *} \\
(0.21)\end{array}$ \\
\hline Respondent controls & Yes & Yes & Yes & Yes \\
\hline Ethnic group controls & Yes & Yes & Yes & Yes \\
\hline Number of respondents & 4703 & 4703 & 4703 & 4703 \\
\hline Number of ethnic groups & 44 & 44 & 44 & 44 \\
\hline Number of regions & 64 & 64 & 64 & 64 \\
\hline Country fixed effects & Yes & Yes & Yes & Yes \\
\hline Adjusted $\mathrm{R}^{2}$ & 0.08 & 0.09 & 0.09 & 0.09 \\
\hline
\end{tabular}

The table reports OLS estimates. The unit of observation is an individual. The respondent controls are Age and its squared term, Female, and Rural location. The ethnic group controls include pre-agreement battle related deaths and pre-agreement power status fixed effects. Standard errors are clustered on ethnic groups. ${ }^{+},{ }^{*},{ }^{* *}$, and ${ }^{* * *}$ indicate statistical significance at the $10,5,1$, and $0.1 \%$ levels.

set. In contrast to the static measure of power access captured by Access to power one year after PA (see previous paragraph), Power upgrade after PA reflects a change in power status. Such a change in power status was visible in Liberia, for instance, where the Gio and Mano improved their power status from junior partner to senior partner through their formal inclusion in Liberia's transitional government. They did not, however, have any formal links to the rebel groups in Liberia's civil war that gained the majority of cabinet seats in the transitional power-sharing government between 2003 and 2005. The coefficient for Power upgrade after PA is positive, large, and statistically significant. This suggests that improvements in the political power status of respondent's ethnic groups do indeed improve their perception of individual living conditions. Nevertheless, our main findings remain unchanged.

Model 11 and 12 in Table 5 explore whether our finding is robust to changes in an ethnic group's power configurations in the period between the peace agreement and the Afrobarometer survey round. Since the Afrobarometer surveys are conducted between 9 to 12 years after the peace agreements, political changes between the peace agreement and the survey round might affect respondents' views about their living conditions. 
Consequently, we add the variables Power upgrade after PA and before survey round and Power downgrade after PA and before survey round to our baseline specification. The variables capture the number of power improvements/downgrades of a respondent's ethnic group in the period between peace agreement and survey round. Interestingly, we find that high numbers of both power upgrades and downgrades reduce a respondent's reported living conditions. This is most likely due to the fact that frequent power upgrades are typically also accompanied by power downgrades when an ethnic group frequently gains and loses access to power. Both measures therefore reflect the volatility of an ethnic group's power access_-and we find that a large volatility of power access reduces reported living conditions. Our main coefficient remains relatively unchanged, however. ${ }^{17}$

\subsection{Interviewer Effects in Survey Interviews}

In a final step, we explore the validity of the used Afrobarometer survey data. Survey interviews are a social interaction between interviewer and respondent and the answers obtained in such interviews can be biased by the context of the interviews. We therefore run a series of regression models to check whether our main results hold once we control for interview and interviewer characteristics.

Table 6 reports the results of these regressions. We again take Model 4 as our baseline model. To all estimated models we add a dummy variable differentiating between the survey rounds used in our sample ${ }^{18}$ and whether the interview was held in the respondent's home language (Lee and Pérez 2014; Pérez 2009). With one exception, the coefficient of the former variable is statistically significant with a negative sign in all models. This indicates that there are systematic differences in the organization of the two survey rounds used in our sample (Adida et al. 2016, 1637). In contrast, the variable Interview in respondent's home language fails to reach substantial levels of statistical significance throughout all models. There seems to be no language-of-interview effects present in our sample.

In Model 13, we also replace the country fixed effects with interviewer fixed effects. Interviewer fixed effects allow us to control for any bias arising from the characteristics of the interviewers as, for example, their age, gender, education, or ethnicity. However, our main results hold: Power-sharing is statistically significant with a positive sign. Only the effect size is now considerably smaller. This reduction is similar to the one we observed

\footnotetext{
${ }^{17}$ Note that both variables are post-treatment variables in the sense that they are measured after the treatment (power-sharing in the peace agreement) and also potentially influenced by the treatment itself, potentially introducing post-treatment bias (Angrist and Pischke 2009). We therefore caution against overinterpreting the coefficient of interest in Model 11 and 12.

${ }^{18}$ With the exception of model 15 which only uses data from survey round 6.
} 
Table 6. Exploring Interviewer Effects

\begin{tabular}{|c|c|c|c|c|c|c|}
\hline & Model 13 & Model 14 & Model 15 & Model 16 & Model 17 & Model 18 \\
\hline Power-sharing & $\begin{array}{r}0.20^{*} \\
(0.08)\end{array}$ & $\begin{array}{c}0.80^{* * * *} \\
(0.10)\end{array}$ & $\begin{array}{c}0.33^{+} \\
(0.15)\end{array}$ & $\begin{array}{l}0.79^{* * *} \\
(0.10)\end{array}$ & $\begin{array}{l}0.79^{* * *} \\
(0.10)\end{array}$ & $\begin{array}{l}0.79^{* * * *} \\
(0.10)\end{array}$ \\
\hline \multicolumn{7}{|l|}{ Interview characteristics } \\
\hline Afrobarometer Survey Round 6 & $\begin{array}{c}-0.03 \\
(0.21)\end{array}$ & $\begin{array}{c}-0.71^{* *} \\
(0.23)\end{array}$ & & $\begin{array}{c}-0.71^{* *} \\
(0.23)\end{array}$ & $\begin{array}{c}-0.70^{* *} \\
(0.23)\end{array}$ & $\begin{array}{c}-0.71^{* *} \\
(0.23)\end{array}$ \\
\hline Interview in respondent's home language & $\begin{array}{c}-0.07^{+} \\
(0.03)\end{array}$ & $\begin{array}{c}-0.14 \\
(0.11)\end{array}$ & $\begin{array}{c}0.00 \\
(0.10)\end{array}$ & $\begin{array}{c}-0.11 \\
(0.12)\end{array}$ & $\begin{array}{c}-0.11 \\
(0.12)\end{array}$ & $\begin{array}{c}-0.11 \\
(0.12)\end{array}$ \\
\hline Interviewer and respondent share language & & $\begin{array}{c}0.09 \\
(0.10)\end{array}$ & & & & \\
\hline Interviewer and respondent share ethnic identity & & & $\begin{array}{c}0.12 \\
(0.09)\end{array}$ & & & \\
\hline \multicolumn{7}{|l|}{ Respondent perceptions } \\
\hline Government perceived as survey sponsor & & & & $\begin{array}{c}-0.08 \\
(0.07)\end{array}$ & & \\
\hline Respondent was hostile & & & & & $\begin{array}{c}0.33 \\
(0.20)\end{array}$ & \\
\hline Respondent was suspicious & & & & & & $\begin{array}{c}-0.14 \\
(0.11)\end{array}$ \\
\hline Constant & $\begin{array}{l}3.15^{* * *} \\
(0.16)\end{array}$ & $\begin{array}{l}3.61^{* * * *} \\
(0.20)\end{array}$ & $\begin{array}{l}3.52^{* * * *} \\
(0.25)\end{array}$ & $\begin{array}{l}3.66^{* * *} \\
(0.20)\end{array}$ & $\begin{array}{l}3.62^{* * *} \\
(0.20)\end{array}$ & $\begin{array}{l}3.63^{* * *} \\
(0.20)\end{array}$ \\
\hline Respondent controls & Yes & Yes & Yes & Yes & Yes & Yes \\
\hline Ethnic group controls & Yes & Yes & Yes & Yes & Yes & Yes \\
\hline Number of respondents & 4703 & 4703 & 2371 & 4703 & 4703 & 4703 \\
\hline Number of ethnic groups & 44 & 44 & 13 & 44 & 44 & 44 \\
\hline Number of regions & 64 & 64 & 45 & 64 & 64 & 64 \\
\hline Country fixed effects & No & Yes & Yes & Yes & Yes & Yes \\
\hline Interviewer fixed effects & Yes & No & No & No & No & No \\
\hline Adjusted $\mathrm{R}^{2}$ & 0.25 & 0.09 & 0.03 & 0.09 & 0.08 & 0.08 \\
\hline
\end{tabular}

The table reports OLS estimates. The unit of observation is an individual. The respondent controls are Age and its squared term, Female, and Rural location. The ethnic group controls include pre-agreement battle related deaths and pre-agreement power status fixed effects. Standard errors are clustered on ethnic groups. ${ }^{+},{ }^{*},{ }^{* *}$, and ${ }^{* * *}$ indicate statistical significance at the $10,5,1$, and $0.1 \%$ levels.

in Model 6 and is probably due to the same reasons. As Adida et al. (2016, 1636f) explain, Afrobarometer interviewers are not assigned randomly but are deliberately deployed to particular geographic regions. It is therefore likely that interviewer fixed effects control for similar factors than region fixed effects. This might also explain why Model 13 is the only model in addition to the one using region fixed effect where Rural location is statistically significant (coefficient not reported in Table 6).

Next, we explore coethnicity effects in Model 14 and 15. Adida et al. (2016) find that respondents give systematically different answers to co-ethnic and non-co-ethnic interviewers in Afrobarometer surveys. They argue that respondents are likely to give socially more desirable answers if the interviewer is from a different ethnic group than them. This finding is of utmost importance for the present study as our theoretical argument puts respondents' ethnicity front and center. Unfortunately, we do not have systematic data on interviewers' ethnicity. The publicly available Afrobarometer Round 5 survey datasets do not include information on interviewers' ethnicity. Despite it being an imperfect proxy, we therefore resort to language to explore co-ethnicity effects and 
include a dummy variable indicating whether respondent and interviewer speak the same home language in Model 14. The coefficient is not statistically significant while Power-sharing is not affected.

In Model 15, we make use of the available Round 6 data on interviewer ethnicity and run our model only on Ivory Coast and Senegal. Our main variable of interest-Powersharing - is now only statistically significant at the $p<0.1$ level. However, this might be due to the fact that after the removal of Liberia and Sierra Leone, Ivory Coast is the only remaining case of power-sharing. The more important finding, however, is that we still do not find any evidence for co-ethnicity effects. The variable Interviewer-respondent coethnicity is statistically not significant.

In Model 16, we explore whether respondents' answers are biased when they think the interviewers are sent by the government. The perception of the government as the survey sponsor might affect how respondents from previously rebellious ethnic groups respond to questions on their living conditions. They might either give socially desirable answers or they might voice their grievances in more extreme ways. Again, however, we do not find any evidence of bias and our main results hold. The final two models control for respondents' attitudes during the interview. Adida et al. (2016) find that respondents interviewed by non-coethnics are more hostile and more suspicious than respondents interviewed by coethnics. We therefore include the variables Respondent was hostile and Respondent was suspicious to proxy for these effects. As in all the other models, we do not find any empirical evidence for systematic bias.

\section{Discussion}

In this paper, we present empirical evidence that individuals' ethnic links to rebel organizations in power-sharing arrangements systematically shape their perception of well-being in the aftermath of conflict. If an individual's ethnic group is included in a power-sharing arrangement at the elite level, they report a 0.2 to 0.8 points higher satisfaction with living conditions than individuals without this representation. This effect is not driven by systematic differences in power access of ethnic groups, respondents' living conditions, or exposure to battle violence. We also do not find evidence that the link between power-sharing at the elite level and differences in well-being at the individual are simply an expression of a country's general tendency for ethnic favoritism or systematically driven by interviewer effects.

We interpret these result in line with a theory of ethnic politics after civil war. Combining concepts from the literature on horizontal inequalities with explanations from the distributive politics literature, we introduce a theory of post-war ethnic favoritism. 
Co-ethnic representation through power-sharing at the elite level increases opportunities for individuals to profit from distributive politics, improves their psychological utility of having co-ethnics in office, and reduces fear of ethnic discrimination. As a consequence, individuals with ethnic links to rebel organizations in power-sharing arrangements exhibit higher scores on Afrobarometer's well-being measures.

Future research should probe these mechanisms more thoroughly. While the three theoretical channels we propose are not mutually exclusive, better empirical evidence on the precise conditions under which each channel becomes most important for individual well-being would improve our understanding of peace processes and ethnic politics more generally. Moreover, we believe that more research is necessary to gauge the generalizability of these findings. In this study, we leveraged ethnic links between individuals and rebel organizations to identify plausible theoretical mechanisms and to structure our empirical investigation around four post-war countries where these mechanisms are plausibly at play. Yet the theoretical mechanisms of distributive politics, psychological utility, and physical protection plausibly also apply to insurgencies that are structured around ideological or other social cleavages. Investigating the precise extent to which this generalization holds is therefore a fruitful avenue for future research.

In documenting systematic differences in well-being between individuals with and without ethnic links to rebel organizations in power-sharing arrangements, we also steer the study of the conflict-inducing effects of horizontal inequalities in a new direction. While prior work has largely focused on inequalities on the group level (Vogt et al. 2015; Cederman and Vogt 2017), shifting the focus on links between elite and micro-levels opens up new questions: is elite accommodation of political power sufficient to reduce ethnonationalist grievances (Wucherpfennig et al. 2012)? Or does this accommodation have to be accompanied by a peace dividend for the broader ethnic group? Our approach, as well as the novel linkage between Afrobarometer, PSED, and EPR data sets promises useful insights into these questions in the future.

Finally, this study has focused only on a very specific type of power transitions: peace agreements. While this type is arguably relevant for both theory and policy of peacebuilding, we encourage future research to study the link between ethnic power transitions and individual well-being more broadly. Such a broader link would enable us to compare between types of ethnic power transitions, ethnic favoritism, and individual well-being and, thus, improve our knowledge about ethnic politics beyond a specific post-war focus. 


\section{References}

Addison, Tony, and Syed Mansoob Murshed. 2003. "Debt Relief and Civil War." Journal of Peace Research 40(2): 159-176.

Adida, Claire L., Karen E. Ferree, Daniel N. Posner, and Amanda Lea Robinson. 2016. "Who's Asking? Interviewer Coethnicity Effects in African Survey Data." Comparative Political Studies 49(12): 1630-1660.

Allansson, Marie, Erik Melander, and Lotta Themnér. 2017. "Organized Violence, 1989-2016." Journal of Peace Research 54(4): 574-587.

Angrist, Joshua D., and Jörn-Steffen Pischke. 2009. Mostly Harmless Econometrics: An Empiricist's Companion. Princeton, NJ: Princeton University Press.

Bates, Robert H. 1974. "Ethnic Competition and Modernization in Contemporary Africa." Comparative Political Studies 6(4): 457-484.

Blattman, Christopher, and Edward Miguel. 2010. "Civil War." Journal of Economic Literature 48(1): 3-57.

Bratton, Michael, and Nicolas Van de Walle. 1994. "Neopatrimonial Regimes and Political Transitions in Africa." World Politics 46(4): 453-489.

Bueno de Mesquita, Bruce, Alastair Smith, Randolph M. Siverson, and James D. Morrow. 2003. The Logic of Political Survival. Cambridge, MA: MIT Press.

Burgess, Robin, Remi Jedwab, Edward Miguel, Ameet Morjaria, and Gerard Padró i Miquel. 2015. "The Value of Democracy: Evidence from Road Building in Kenya." American Economic Review 105(6): 1817-1851.

Cameron, A. Colin, Jonah B. Gelbach, and Douglas L. Miller. 2011. "Robust Inference With Multiway Clustering." Journal of Business \& Economic Statistics 29(2): 238-249.

Cederman, Lars-Erik, and Manuel Vogt. 2017. "Dynamics and Logics of Civil War." Journal of Conflict Resolution, 0022002717721385.

Cederman, Lars-Erik, Andreas Wimmer, and Brian Min. 2010. "Why Do Ethnic Groups Rebel? New Data and Analysis." World Politics 62(1): 87-119.

Cederman, Lars-Erik, Kristian Skrede Gleditsch, and Halvard Buhaug. 2013. Inequality, Grievances, and Civil War. Cambridge: Cambridge University Press.

Cederman, Lars-Erik, Nils B. Weidmann, and Kristian Skrede Gleditsch. 2011. "Horizontal Inequalities and Ethnonationalist Civil War: A Global Comparison." American Political Science Review 105(3): 478-495. 
Clapham, Christopher, ed. 1998. African Guerrillas. Oxford: James Currey.

Collier, Paul, V.L. Elliot, Håvard Hegre, Anke Hoeffler, Marta Reynal-Querol, and Nicholas Sambanis. 2003. Breaking the Conflict Trap: Civil War and Development Policy. Washington, DC: World Bank and Oxford University Press.

Denny, Elaine K, and Barbara F Walter. 2014. "Ethnicity and Civil War." Journal of Peace Research 51(2): 199-212.

Eifert, Benn, Edward Miguel, and Daniel N. Posner. 2010. "Political Competition and Ethnic Identification in Africa." American Journal of Political Science 54(2): 494-510.

Flores, Thomas Edward, and Irfan Nooruddin. 2009. "Democracy under the Gun Understanding Postconflict Economic Recovery." Journal of Conflict Resolution 53(1): 329.

Franck, Raphaël, and Ilia Rainer. 2012. "Does the Leader's Ethnicity Matter? Ethnic Favoritism, Education, and Health in Sub-Saharan Africa." American Political Science Review 106(2): 294-325.

Francois, Patrick, Ilia Rainer, and Francesco Trebbi. 2015. "How Is Power Shared in Africa?" Econometrica 83(2): 465-503.

Garriga, Ana Carolina, and Brian J. Phillips. 2014. "Foreign Aid as a Signal to Investors: Predicting FDI in Post-Conflict Countries." Journal of Conflict Resolution 58(2): 280306.

Gates, Scott, Benjamin A. T. Graham, Yonatan Lupu, Håvard Strand, and Kaare W. Strøm. 2016. "Power Sharing, Protection, and Peace." The Journal of Politics 78(2): 512-526.

Girardin, Luc, Philipp Hunziker, Lars-Erik Cederman, Nils-Christian Bormann, and Manuel Vogt. 2015. "GROWup: Geographical Research On War, Unified Platform." ETH Zurich. http://growup.ethz.ch/.

Gleditsch, Nils Petter, Peter Wallensteen, Mikael Eriksson, Margareta Sollenberg, and Håvard Strand. 2002. "Armed Conflict 1946-2001: A New Dataset." Journal of Peace Research 39(5): 615-637.

Golden, Miriam, and Brian Min. 2013. "Distributive Politics Around the World." Annual Review of Political Science 16(1): 73-99.

Haass, Felix, and Martin Ottmann. 2017. "Profits from Peace: The Political Economy of Power-Sharing and Corruption." World Development 99: 60-74. 
Habyarimana, James, Macartan Humphreys, Daniel N. Posner, and Jeremy M. Weinstein. 2007. "Why Does Ethnic Diversity Undermine Public Goods Provision?" American Political Science Review 101(4): 709-725.

Harbom, Lotta, Erik Melander, and Peter Wallensteen. 2008. "Dyadic Dimensions of Armed Conflict, 1946-2007." Journal of Peace Research 45(5): 697-710.

Harbom, Lotta, Stina Högbladh, and Peter Wallensteen. 2006. "Armed Conflict and Peace Agreements." Journal of Peace Research 43(5): 617-631.

Hartzell, Caroline A., and Matthew Hoddie. 2007. Crafting Peace: Power-Sharing Institutions and the Negotiated Settlement of Civil Wars. University Park, PA: Pennsylvania State University Press.

Howe, L. D., J. R. Hargreaves, S. Gabrysch, and S. R. A. Huttly. 2009. "Is the Wealth Index a Proxy for Consumption Expenditure? A Systematic Review." Journal of Epidemiology \& Community Health 63(11): 871-877.

Humphreys, Macartan, and Jeremy M. Weinstein. 2008. "Who Fights? The Determinants of Participation in Civil War." American Journal of Political Science 52(2): 436-455.

Jablonski, Ryan S. 2014. "How Aid Targets Votes: The Impact of Electoral Incentives on Foreign Aid Distribution." World Politics 66(2): 293-330.

Jarstad, Anna K., and Ralph Sundberg. 2007. "Peace by Pact: Data on the Implementation of Peace Agreements." In Globalization and Challenges to Building Peace, eds. Ashok Swain, Ramses Amer, and Joakim Öjendal. London: Anthem Press , 73-89.

Joshi, Madhav, Erik Melander, and Jason Michael Quinn. 2017. "Sequencing the Peace: How the Order of Peace Agreement Implementation Can Reduce the Destabilizing Effects of Post-Accord Elections." Journal of Conflict Resolution 61(1): 4-28.

Kahneman, Daniel, and Alan B. Krueger. 2006. "Developments in the Measurement of Subjective Well-Being." The Journal of Economic Perspectives 20(1): 3-24.

Kalyvas, Stathis N. 2006. The Logic of Violence in Civil War. Cambridge: Cambridge University Press.

Kasara, Kimuli. 2007. "Tax Me If You Can: Ethnic Geography, Democracy, and the Taxation of Agriculture in Africa." American Political Science Review 101(1): 159-172.

Kramon, E., and D. N. Posner. 2016. "Ethnic Favoritism in Education in Kenya." Quarterly Journal of Political Science 11(1). 
Kramon, Eric, and Daniel N. Posner. 2013. "Who Benefits from Distributive Politics? How the Outcome One Studies Affects the Answer One Gets." Perspectives on Politics 11(2): 461-474.

Kreutz, Joakim. 2010. "How and When Armed Conflicts End: Introducing the UCDP Conflict Termination Dataset." Journal of Peace Research 47(2): 243-250.

Lakner, Christoph, and La-Bhus Fah Jirasavetakul. 2016. The Distribution of Consumption Expenditure in Sub-Saharan Africa : The Inequality among All Africans. Technical Report WPS7557 The World Bank.

Lee, Taeku, and Efrén O. Pérez. 2014. "The Persistent Connection Between Language-ofInterview and Latino Political Opinion." Political Behavior 36(2): 401-425.

Licklider, Roy, ed. 1995. Stopping the Killing: How Civil Wars End. New York: NYU Press.

Lieberman, Evan S. 2015. "The Comparative Politics of Service Delivery in Developing Countries.".

Lieberman, Evan S., and Gwyneth H. McClendon. 2013. "The Ethnicity-Policy Preference Link in Sub-Saharan Africa." Comparative Political Studies 46(5): 574-602.

Olson, Mancur. 1971. The Logic of Collective Action. Public Goods and the Theory of Groups. 2nd ed. Cambridge, MA: Harvard University Press.

Ottmann, Martin. 2017. "Rebel Constituencies and Rebel Violence against Civilians in Civil Conflicts." Conflict Management and Peace Science 34(1): 27-51.

Ottmann, Martin, and Johannes Vüllers. 2015. "The Power-Sharing Event Dataset (PSED): A New Dataset on the Promises and Practices of Power-Sharing in PostConflict Countries." Conflict Management and Peace Science 32(3): 327-350.

Padró i Miquel, Gerard. 2007. "The Control of Politicians in Divided Societies: The Politics of Fear." The Review of Economic Studies 74(4): 1259-1274.

Pérez, Efrén O. 2009. "Lost in Translation? Item Validity in Bilingual Political Surveys." The Journal of Politics 71(4): 1530-1548.

Posner, Daniel N. 2005. Institutions and Ethnic Politics in Africa. Cambridge University Press.

Robinson, Amanda Lea. 2014. "National Versus Ethnic Identification in Africa: Modernization, Colonial Legacy, and the Origins of Territorial Nationalism." World Politics 66(4): 709-746. 
Roessler, Philip. 2016. Ethnic Politics and State Power in Africa: The Logic of the Coup-Civil War Trap. Cambridge University Press.

Stewart, Frances. 2008. "Horizontal Inequalities and Conflict: An Introduction and Some Hypotheses." In Horizontal Inequalities and Conflict. Conflict, Inequality and Ethnicity Palgrave Macmillan, London , 3-24.

Stokes, Susan Carol, Thad Dunning, Marcelo Nazareno, and Valeria Brusco. 2013. Brokers, Voters, and Clientelism: The Puzzle of Distributive Politics. Cambridge: Cambridge University Press.

Themnér, Anders, and Mats Utas. 2016. "Governance through Brokerage: Informal Governance in Post-Civil War Societies." Civil Wars 18(3): 255-280.

Tull, Denis M., and Andreas Mehler. 2005. "The Hidden Costs of Power-Sharing: Reproducing Insurgent Violence in Africa." African Affairs 104(416): 375-398.

Utas, Mats. 2012. "Introduction: Bigmanity and Network Governance in African Conflicts." In African Conflicts and Informal Power. Big Men and Networks, ed. Mats Utas. London, New York: Zed Books, 1-31.

Vogt, Manuel, Nils-Christian Bormann, Seraina Rüegger, Lars-Erik Cederman, Philipp Hunziker, and Luc Girardin. 2015. "Integrating Data on Ethnicity, Geography, and Conflict: The Ethnic Power Relations Data Set Family." Journal of Conflict Resolution 59(7): 1327-1342.

Wagner, R. Harrison. 2000. "Bargaining and War." American Journal of Political Science 44(3): 469-484.

Wallensteen, Peter. 2015. Quality Peace. Strategic Peacebuilding and World Order. Oxford: Oxford University Press.

Weinstein, Jeremy M. 2007. Inside Rebellion: The Politics of Insurgent Violence. Cambridge: Cambridge University Press.

Wittman, Donald. 1979. "How a War Ends: A Rational Model Approach." Journal of Conflict Resolution 23(4): 743-763.

Wucherpfennig, Julian, Nils W. Metternich, Lars-Erik Cederman, and Kristian Skrede Gleditsch. 2012. "Ethnicity, the State, and the Duration of Civil War." World Politics 64(1): 79-115. 